\title{
THE READINESS OF INSTITUTION, SUPPORTING AND INHIBITING FACTORS AS WELL AS STRATEGY IN ENHANCING THE QUALITY OF STUDENTS' SCIENTIFIC WORK PUBLICATION
}

\author{
Achmad Supriyanto * \\ Burhanuddin ** \\ Raden Bambang Sumarsono $* * *$ \\ * FIP Universitas Negeri Malang, aspriess@gmail.com, 081334096498 \\ ** FIPUniversitas Negeri Malang, handj_scorp@yahoo.com \\ *** FIP Universitas Negeri Malang, rbamsum@gmail.com
}

\begin{abstract}
This research aims to examine the readiness of institution, supporting and inhibiting factors as well as strategy in enhancing the quality of students'scientific work publication. This study used descriptive research design. The population consisted of the chairmen of institutions and the journal manager. The data was collected by using questionnaire and analyzed by using descriptive statistic. The results show that the institutions are ready to enhance the quality of students' scientific work publication. However, the implementation has not been optimal. The factors supporting the not optimal implementation came from the aspect of chairmen and journal manager. Meanwhile, the inhibiting factors derived from the chairmen of the institution who have not optimally given a reward. The institution strategy is still obligating the students to publish their scientific works in the required journals including the international ones.
\end{abstract}

Keywords: enhancement strategy, publication quality, students' scientific paper

\section{INTRODUCTION}

In the last five years, General Directorate of High Education [1], Ministry of Education and Culture, Republic of Indonesia have issued some policies regarding education implementation including high education in Indonesia. One of the policies paid attention of by the academicians is the Circular Letter of General Directorate of High Education Number 152/E/T/2012 about Scientific Work Publication. The Circular Letter contains two things: the fundamental reason behind the letter and the content. The apparent reason is that "the number of scientific work publication from the college in Indonesia is still low; if it is compared to Malaysia, it is only one of seven." The reason is rational enough since Indonesian Scientific Journal Database [2] states that:

... there are about 13.047 journals in

Indonesia categorized as scientific, and they are still active, but they are left behind by Malaysia reaching 55.211 and Thailand reaching 58.931 journals. Since 2010, from the total journals of Indonesia, only around 121 journals that have been accredited by Dirjen Dikti; the scientific works produced by Indonesian is one of seven from the scientific works produced by the universities in Malaysia.

Based on the data of SCImago Journal \& Country Rank (2013) that has recorded the number of scientific publication in SCOPUS, the publication of Indonesia is presented in Figure 1. The number of Indonesian's publication of Indonesia drastically increases from year to year, but if it is compared to America, Japan and so forth, we can see that the number of Indonesian's publication is nothing, so Indonesia is in the 64th position from 236 countries (Bachtiar, 2013). 


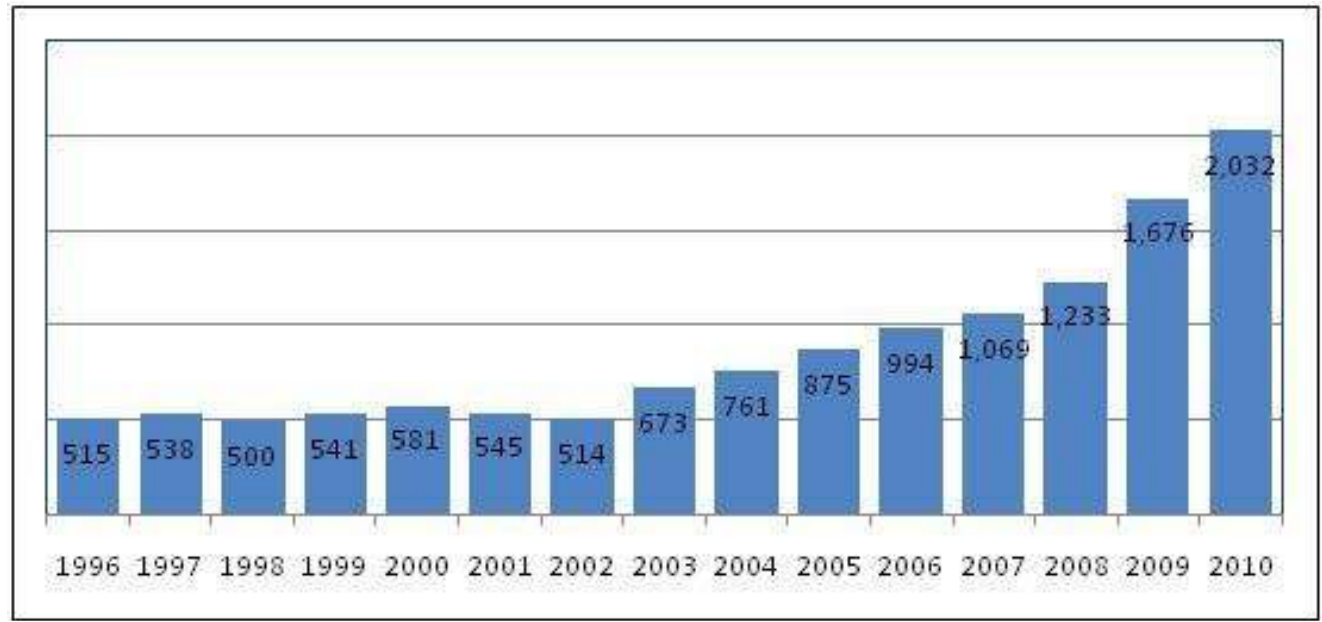

Figure 1. The Number of Indonesian's Publication in the Period of 1996-2010 (Data of SCImagoJR)

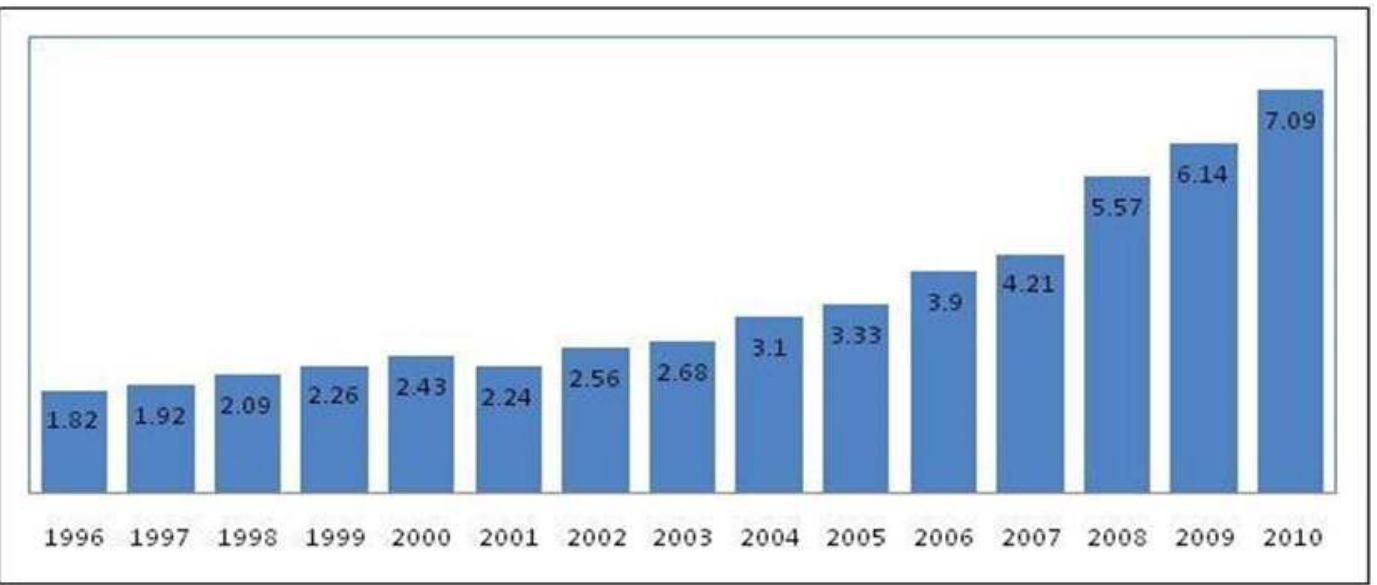

Figure 2. Ratio of Malaysian Scientific Publication to the Indonesian one (analyzed from the data of SCImagoJR)

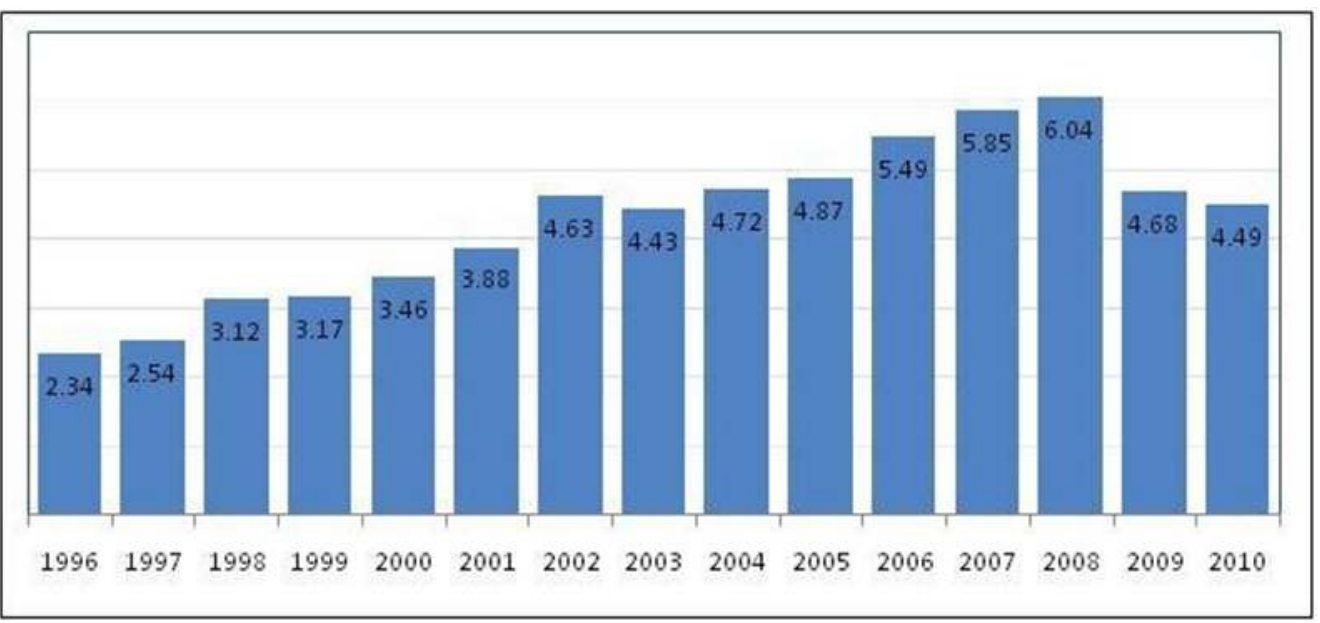

Figure3. Ratio of Thailand Scientific Publication to Indonesia (analyzed from the data of SCImagoJR) 


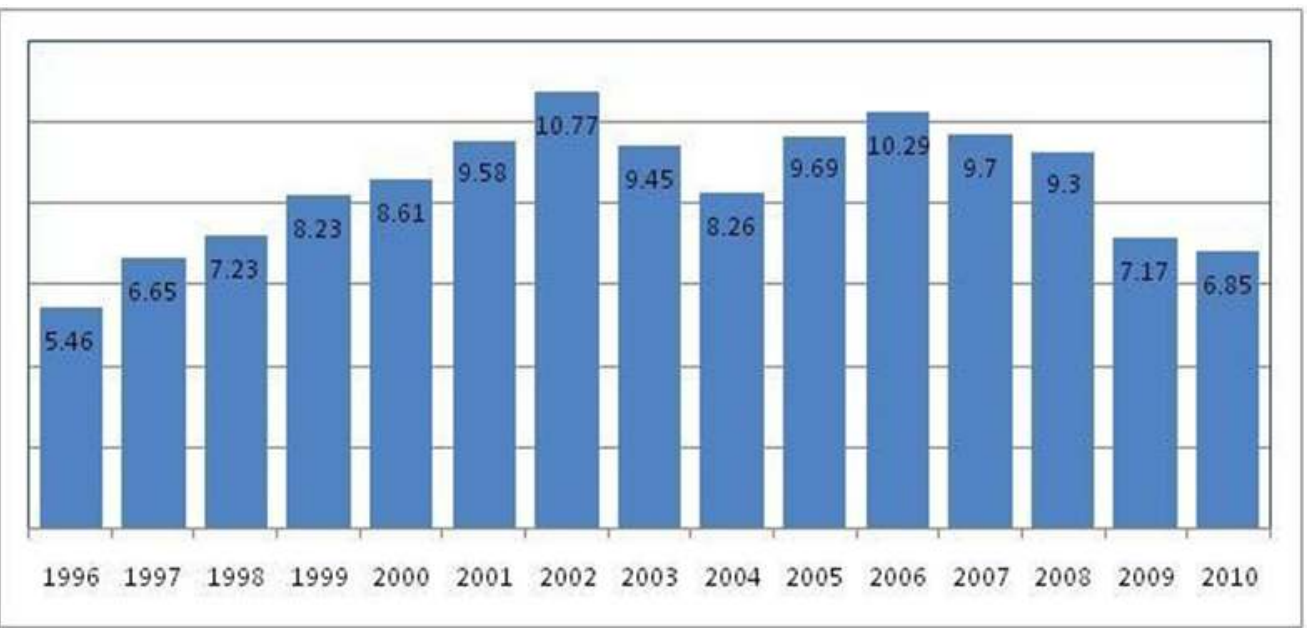

Figure 4. Ratio of Singapore Scientific Work Publication to Indonesia (analyzed from the data of SCImagoJR)

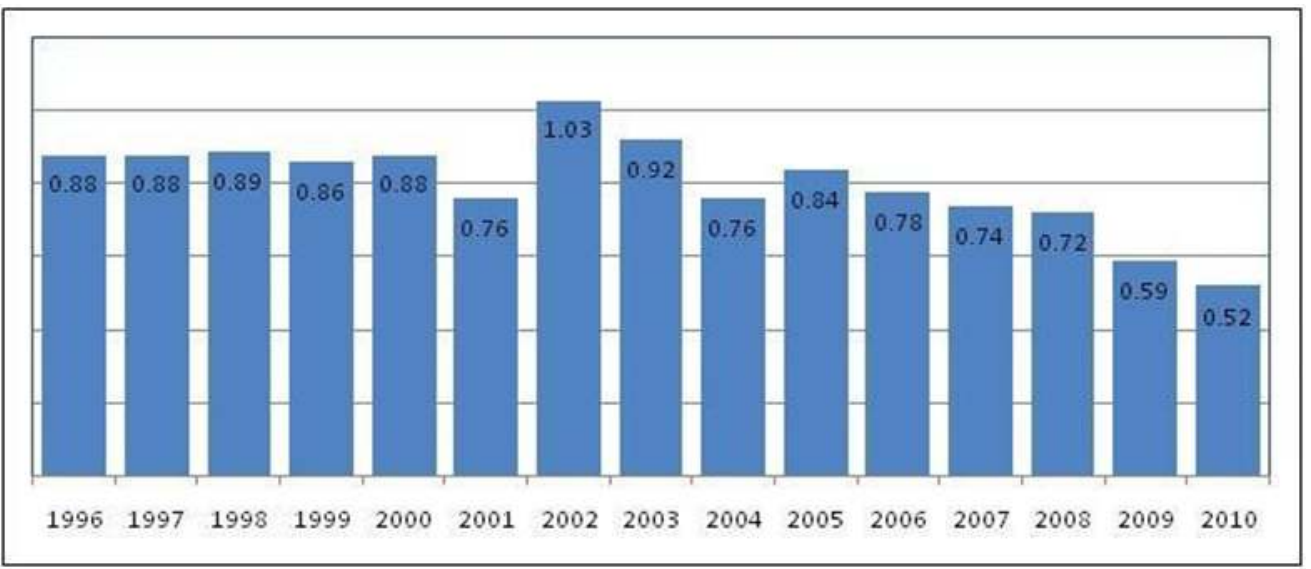

Figure 5. Ratio of Philippine Scientific Journal to Indonesia (analyzed from the data of SCImagoJR)

[3] also shows that the consistency of Indonesia increases from year to year. This information describes that the willingness of Indonesian authors is relatively good. Unfortunately, the number of publication is alarming if it is compared to the neighbor countries such as Malaysia, Thailand, Singapore, and Philippine. We can see this particular condition can in Figure 2 [3].

Based on Figure 2, publication of Malaysia increases drastically as well from year to year. Its ratio to the Indonesian publication increased from 1.82 times more in 1996; it increased up to 7,09 times more in 2010. Dirjen DIKTI refers to such data.
The scientific publication of Malaysia tends to be good enough. If we refer to the number of publication in 2010, Malaysia reached the highest number of the ASEAN countries in term of scientific publication. The data describes that the stakeholders especially High Education (DIKTI) and the academicians in Indonesia should pay attention to the journal of Indonesia to build academic atmosphere through the published scientific work. Based on such reason, the main content of Circular Letter of General Directorate of DIKTI subsequently states that:

...since the graduation after Agustus 2012, the following regulations will be applied:

a) The graduate of bachelor program must produce a paper published in scientific journal

b) The graduate of magister program must present a paper published in the national scientific journal mainly that has been accredited by DIKTI; 
c) The graduate of the Doctoral program must provide a paper accepted to be published in the international journal.

Such policies are seemed to be reactive to the atmosphere of scientific publication in Indonesia now on. The implementation relatively makes the universities are not ready, and the students as well as lecturers feel "unpleasant." One of the people's responses toward the circular letter is stated by [2] as following:

Beyond such controversy, we should still support since the goal is excellent, it is to increase the number of scientific work publication of academicians in Indonesia. Therefore, starting from now, state and private colleges should think about how to improve the supporting facility and infrastructure in writing a scientific paper and how to publish it based on the standard.

The factor of human resource readiness in the university has not been equal yet, so it needs to study. Because the goal is exquisite, however, the policy of scientific work publication should be supported by the college. The chairmen of college, rector and the leader of the director must socialize, prepare, implement and evaluate in each academic area.

Some things that should be highlighted is the Circular Letter of General Directorate of DIKTI implicating that scientific work publication should be accomplished as one of requirements of $\mathrm{S} 1$ (bachelor program), S2 (magister program) and S3 (doctoral program) graduates. If such requirement is conducted well, the umber of scientific work publication in Indonesia can compete with other countries. The implementation is not easy at the first step; many problems should be covered by this research.

The problems are, for example, related to the readiness of college, the number of college that has implemented or has not, the supporting factors, the inhibiting factors, the solution to solve the inhibiting factors as well as any recommendation prepared by the colleges in Indonesia to implement the Circular Letter of DIKTI. Such problems are covered in this research through a study entitled "The Readiness of Institution, Supporting and Inhibiting Factors and the Strategy in Enhancing the Students' Scientific Work Publication Quality."

Conceptually, scientific work is an English term. Definitively, scientific work means a written report, and it is published by explaining the research result or study conducted by a researcher or a team based on the rule and science ethics upheld and obeyed by the science community [4]. A Scientific work is a work of a scientist intending to develop the science, knowledge, technology and art through literature, a group of experience and the others knowledge previously (Fali, 2013). Scientific work is " a scientific work/writing of someone based on the rational truth of logic and scientific truth" (Facthan, 2008). More obviously and firmly, a scientific work is a scientific writing originated from the research results or not research results. Such works such as bachelor thesis, Magister thesis, dissertation and the other research results as well as articles, journals, papers, teaching books and so forth (Universitas Negeri Malang, 2000). A Scientific paper is someone's work written based on the research results and not research results. Through the written scientific work, someone can communicate new information, idea, the study of the research results to the others scientifically.

Some scientific works can be in the form of the research report, seminar paper, symposium paper, and an article published in a certain journal. The peculiarity of such scientific papers is the work derived from a scientist' process. The process is usually begun from the data collection to answer the research problems, data analysis, discussion, conclusion, and recommendation.

The activity of introducing and processing a scientific work in the colleges in Indonesia has been conducted for a long time. A Scientific paper in a college is typically classified into some types such as bachelor thesis, Magister thesis, dissertation, article, paper and teaching book (Facthan,2008:6). Some models of scientific papers such as bachelor thesis, Magister thesis, dissertation, article, paper and teaching book are made since they are very beneficial for the academic communities in the college. There are some purposes of scientific work writing applied by the university to the students. Fali (2013:1) states that the purposes of scientific work writing are:

a) As a media to train expressing thought or the research results in the form of a systematical and methodological scientific writing.

b) Encouraging the scientific ethos in the students, so they do not only become the knowledge consumer but also being able to produce a thought and scientific work especially after completing their studies.

c) The scientific works that have been written are expected to be a transformation media of knowledge between school and society or among people who are interested in reading them.

d) Proving the potential and scientific knowledge of the students in facing and solving any problems in the form of 
scientific work after they get knowledge and education from their department.

e) Training the basic skill to conduct a research.

The author should mean in achieving the goals mentioned above to get a qualified result. The students, through scientific work writing, can train themselves to deliver their thought and research results, build their scientific ethos, have a knowledge transformation media and actualize themselves in the field they have chosen.

There are some advantages of a scientific work for the author. Fadli (2013) formulates the benefits of a scientific paper for the author such as:

a) Training to develop the effective reading skill;

b) Training to combine the result of reading from any sources;

c) Introducing the literary activity;

d) Enhancing the organizing fact/data clearly and systematically;

e) Getting the intellectual satisfaction;

f) Broadening the knowledge insight;

g) As a reference/pilot research for further research

The benefit of scientific work is not only for the author, but more than that, it is beneficial to see the progress and achievement of a college in the level of national, regional and international. Such advantages can be perceived when the scientific work is published in the local, national or international journal based on the accreditation status.

The word 'publication' is a technical term in the context of constitutional especially the copyright law. In other words, an author of scientific work generally is a first owner of particular copyright for his/her work. The publication means publishing effort as well, and it refers to every copy. Copyright can be given to people due to their work. Meanwhile, publishing is an activity of making the content intended to the public. The use of publishing varies in the form of text, picture, content, visual audio in any printed or electronic media [4].

Someone who has written his/her ideal scientific work can be shared to the others to publish the content. This publication is beneficial; the author can actualize him/herself through any media chosen like a scientific journal. The scientific publication is a "publication system based on peer review to reach the highest objectivity level. This 'system' varies depends on each field, and it always changes gradually. Most of the academic works are published in the form of scientific research or book" [4]. The amount of scientific work is getting larger as the development of science and technology as well as the demand of the candidates of bachelor, Magister and doctoral who have to publish a scientific work in the form of a scientific journal. The available journals are the strategic ones to publish the scientific work.

The publication of scientific work will continue to develop as the development of information technology. The fundamental change is happening today; the journal that is formerly in the form of printed media changes into more complete, easier and faster in accessing it through offline and online electronic journal ( a journal published in the electronic media). This media facilitates the students to publish their scientific works as one of graduation requirements because of the implementation of Circular Letter of Dikti. The claimed problems happen so far can be answered by this media since "the access to the electronic scientific journal is provided openly. This case means that the amount of the scientific publication is getting bigger that can be accessed freely through the internet provided by the journal publisher.

A historical overview shows that one of the scientific journals considered as the earliest publication is Philosophical Transactions of the Royal Society published on XVII century [4]. This particular journal published the research results, but at that moment it was regarded as a controversial thing among the society. A new finding was usually published in the form of an anagram. The form of a journal that could not be understood widely caused the readers were difficult in comprehending the content. Although people did not understand what was being published by anagram, the anagram actually explained the new finding so it could be claimed that the first publisher was the founder.

The scientific work publication among the academicians especially the lecturer in Indonesia has run for a relatively long time. A lecturer can publish the scientific paper in the form of the research results through relevant journal, proceeding, seminar or book to do the tri dharma of college especially in term of research. The publication results are profoundly meaningful especially as the proof of the lecturer's work as well as for the increase of position/rank from the assistant to the great lecturer in a college.

The issuing of Circular Letter of General Directorate of High Education Number $152 / \mathrm{E} / \mathrm{T} / 2012$ about scientific work gives consequence to the university in Indonesia, the state and the private ones to implement it. A college should require the students graduate after August 2012 must publish a scientific work for the S1 (Bachelor degree), S2 (Magister degree) and S3 (doctoral degree). 
Based on the pilot project through some writings, the obligation of writing the scientific work and publishing it in the journal as the graduation requirement of the candidate of bachelor, Magister and doctor has arisen controversy from the level of college to the institution as well as the students that should fulfill such requirement. Some responses are addressed as follow: (1) the implementation of the circular letter is worried can stimulate the rapid spread of jockey since not all students can write; (2) such policy seems immediate and is forced and the doer should prepare properly (3) it is better if the policy is firstly studied as waiting all tools are ready [2].

The pro and contra responses of society to the policy of scientific work publication still occur up to now. The pro response of the policy is stated for example by [5] as follow:

Based on the data of Scimagojr, the number of Indonesian's journal publication was in the rank of 64 from 236 countries that have published the scientific journals with the number of publication were 13.047 in the period of 1996-2010. Malaysia was in the 43rd rank with 55211 publications in the same year. The United State of America published 5.3 million scientific papers and was in the position of country continually publishing a scientific paper.

Based on the data, it could be rational if the circular letter is implemented as an effort of Indonesia to pursue the backwardness in developing the education quality. The Minister of Education and Culture has adequately supported such policy by stating "the scientific work publication is in the form of the synopsis of Bachelor thesis, Magister thesis or dissertation written by the students. This system is not complicated, of course, if the students write their final exams by themselves" (Nong, 2013).

The are some communities in the state and private colleges who show contra response to the scientific work publication. Nong (2013) states that "There is an issue saying that 3.150 private universities refuse the scientific work writing for undergraduate students since it can inhibit their graduation process. The universities recommend the government should prepare available facilities before applying the policy.” Another Nong's (2013) statement related to his contraposition is:

Some state colleges are less appreciative to the journal publication system. The policy is appropriate to improve the graduates' quality and prevent the copy-paste in the context of education. However, the government should consider the available facilities and infrastructures to support the publication as well.

Based on the phenomena of pro and contra responses among the society to the Circular Letter, Djoko Santoso the General Directorate of Dikti Kemdikbud gives some alternativ solutions such as (1) making an online journal guideline in order the institution can access it quickly; (2) Kemdikbud and LIPI attempt cooperatively in order every college has the serial number of international journal; (3) the Center of Data and Scientific Information will handle the publication for S1, while S2 and S3 will be handled by Dikti (Nong, 2013).

The Minister of Education and Culture of RI firmly states the reason of the issuing Circular Letter of Dirjen Dikti. The three reasons stated by Muhammad Nuh as the Minister of Education and Culture are (1) to reduce the plagiarism, (2) to control the originality and plagiarism easily, (3) to accelerate the science development [6]. Such affirmation strengthens the policy of scientific work publication as the requirement of graduation of the candidates of Bachelor, Magister, and doctor in the colleges in Indonesia.

[7] refers to the statement of Dirjen Dikti that essentially the policy is formulated as follow (1) a bachelor should have capability in writing scientifically; (2) when a bachelor is skillful in scientific writing, he/she will be not difficult to make a scientific paper in advanced level and this rule can create the quantity and quality of scientific work produced by Indonesia; and (3) when a bachelor continue his/her study to Magister or Doctoral programs, the writing quality might improve, his/her knowledge will be more global and their works are published in the international journals so they can pursue the left-behind of Indonesia in writing scientific paper.

If we see the phenomena occurring, it can be concluded that the Circular Letter of Dirjen Dikti Kemedikbud about Scientific Paper Publication is still implemented gradually and continually. Although some people deny such policy for some reasons and worries, there is the solution to answer their anxiety. It means that whatever the situation and condition of state and private colleges especially the students, one of graduation requirements is writing a scientific paper and publishing it in the journal. If this policy is successfully implemented, the students can actualize their published scientific work, the government can relieve the plagiarism, and the college can show its quality and Indonesia can pursue its backwardness in term of scientific publication in the international academic development.

Some strategies that can be used by college to improve the quality of the students' scientific paper 
including giving the journal based-task during the lecture, making the task in the form of scientific journal format, training of scientific paper writing, clinic of scientific journal based-scientific paper. The college must be concerned with the quality of its students' scientific paper. The basis is the Circular Letter of Dirjen Dikti number 152/E/T/2012 about scientific work publication. This result is very beneficial to the developing and building process of academic atmosphere among the students as the candidate of Bachelor, Magister, and doctor in the scientific work publication in Indonesia.

\section{METHOD}

Based on purposes, this research used a descriptive quantitative design. This study attempts to describe a symptom, events occurring today or some real problems during the research without any particular treatment of such event [9] especially the implementation of the policy of Dirjen Dikti that becomes the center attention of academicians of college in Indonesia.

The population of this research refers to the statement of [8] addressing that "all research subjects have similar characteristics." The research population consisted of the academic chairmen that are Dean vices and the chairmen of department/study program of each faculty at the State University of Malang (UM). There were 62 populations in this research. This study used saturation sample (total sample). It means that all Dean vices I and the chairmen of the departments in UM were 62 becoming the sample of this work.

The variable of this research consists of the implementation of the Circular Letter of Dirjen Dikti Number 152/E/T/2012 and the Scientific Work Publication. Both variables, sub-variable, and the indicators of this research were developed by the researcher based on the document of circular letter and the relevant literary study as well as the researcher's independent thought.

The instrument of this research is a questionnaire. The questionnaire was developed based on the variables, sub-variables and the indicators of the estimator. The characteristics are close and open. The measurement was by using a Likert scale and statement formulation as well as the alternative answer was based on the indicator of the measurement used in this research.

The data collection was by using the questionnaire as explained before. The questionnaire was given to the respondents as the data source (the chairmen of college for the academic field) directly or indirectly, and practically it was based on the situation and condition through the data collector.

The data collection stage was begun with a technical briefing, area job sharing of the respondent and the questionnaire withdrawal. The data collected was entered, analyzed with the suitable data analysis.

The data collected was analyzed by using descriptive analysis technique. The analysis result can give the information of the institution readiness, supporting and inhibiting factors as well as the strategy for enhancing the quality of the students' scientific work. Practically, this data analysis was assisted by Excel program.

The descriptive analysis technique was used to find the readiness of the institution, supporting and inhibiting factors and the strategy in enhancing the quality of the students' scientific work. The procedure was by using some stages as follow: (a) the collected data was entered into the Excel program; (2) the mean descriptive analysis was done by using Excel program; (3) determining the meaning of each mean referring to the interpretation guideline.

The research was conducted in seven districts in Central Java Province namely Semarang, Batang, Pekalongan, Purbalingga, Banjarnegara, Wonosobo, and Sragen. The selection of districts was done purposively based on USAID PRIORITAS program. Evaluation were made four times at the beginning of the program (2012), the end of year 2 (2013), the end of year 4 (2015), and the 5th year (2016). The evaluation team consisted of teachers, principals, school supervisors, staff of the education office, students of university, and lecturers. Data collection was done with interview, observation, and documentation. Data analysis with percentage and Pearson correlation. Results were compared between partner schools and comparison schools for elementary and junior high schools of SMP-MTs. The number of schools studied was 64 schools consisting of partner schools and comparison schools. Partner schools are schools that receive continuous treament during the program. Treatment was on the form of training and coaching by trained facilitators. Meanwhile, the comparison schools did not get treatment directly, but get the impact or imitate from partner schools.

\section{RESULT}

\subsection{The Readiness of Institution in Enhancing the Quality of the Students' Scientific Work Publication}

The readiness in this context including the readiness of the institution, the implementation of 
the scientific work publication, the type of scientific work and the type of scientific work publication media. The analysis results are presented in Table 1.

Table 1. The Readiness of Institution in Enhancing the Quality of the Students' Scientific Work Publication

\begin{tabular}{|c|c|c|}
\hline Aspect & Mean & Classification \\
\hline \multicolumn{3}{|l|}{ The Readiness of Institution } \\
\hline $\begin{array}{l}\text { The readiness of college in enhancing the quality of } \\
\text { scientific work publication }\end{array}$ & 3,35 & Good \\
\hline $\begin{array}{l}\text { The availability of policy supporting the implementation of } \\
\text { the Circular Letter of Dirjen Dikti }\end{array}$ & 3,33 & Good \\
\hline $\begin{array}{l}\text { Socialization of Circular Letter of Dirjen Dikti Kemdikbud } \\
\text { Number 152/E/T/2012 about Scientific Work Publication }\end{array}$ & 3,15 & Good \\
\hline The college (UM) policy of Scientific Work Publication & 3,52 & Good \\
\hline $\begin{array}{l}\text { The availability of team that will assist the Scientific Work } \\
\text { Publication }\end{array}$ & 3,17 & Good \\
\hline The availability of facilities of Scientific Work Publication & 3,28 & Good \\
\hline $\begin{array}{l}\text { The availability of journal media for Scientific Work } \\
\text { Publication }\end{array}$ & 3,04 & Good \\
\hline $\begin{array}{l}\text { The availability of particular officer helping the Scientific } \\
\text { Work Publication }\end{array}$ & 3,00 & Good \\
\hline Classification & 3,23 & Good \\
\hline Aspect & Mean & Classification \\
\hline \multicolumn{3}{|l|}{ Implementation of Scientific Work Publication } \\
\hline $\begin{array}{l}\text { The faculty of } \mathrm{Mr} / \mathrm{Mrs} / \text { Miss has implemented the Circular } \\
\text { Letter of Dirjen Dikti kemdikbud Number 152/E/T/2012 } \\
\text { about Scientific Work Publication }\end{array}$ & 3,24 & Good \\
\hline $\begin{array}{l}\text { The faculty of } \mathrm{Mr} / \mathrm{Mrs} / \mathrm{Miss} \text { is in the process of } \\
\text { implementing the Circular Letter of Dirjen Dikti kemdikbud } \\
\text { Number } 152 / \mathrm{E} / \mathrm{T} / 2012 \text { about Scientific Work Publication }\end{array}$ & 2,65 & Good Enough \\
\hline $\begin{array}{l}\text { The study program of } \mathrm{Mr} / \mathrm{Mrs} / \mathrm{Miss} \text { has implemented the } \\
\text { Circular Letter }\end{array}$ & 3,09 & Good \\
\hline $\begin{array}{l}\text { The study program of } \mathrm{Mr} / \mathrm{Mrs} / \mathrm{Miss} \text { is in the process of } \\
\text { implementing the Circular Letter }\end{array}$ & 2,56 & Good Enough \\
\hline Classification & 2,88 & Good Enough \\
\hline Aspect & Mean & Classification \\
\hline \multicolumn{3}{|l|}{ Type of Scientific Work } \\
\hline Scientific work relying on the Bachelor thesis & 3,52 & Ready \\
\hline Scientific work relying on the Magister thesis & 2,56 & Ready Enough \\
\hline Scientific work relying on the dissertation & 2,07 & Ready Enough \\
\hline Scientific work in the form of paper & 3,15 & Ready \\
\hline Scientific work as the synopsis of Bachelor thesis & 2,63 & Ready Enough \\
\hline Scientific work as the synopsis of Magister thesis & 2,07 & Ready Enough \\
\hline Scientific work as the synopsis of dissertation & 1,93 & Less \\
\hline
\end{tabular}




\begin{tabular}{|l|c|c|}
\multicolumn{1}{|c|}{ Aspect } & Mean & Classification \\
\hline Type of Scientific Work Publication Media & & \\
\hline Online journal/online media & 2,93 & Ready Enough \\
\hline Journal of study program (not accreditated) & 3,24 & Ready \\
\hline Journal of faculty (not accreditated) & 2,85 & Ready Enough \\
\hline Journal of college (not accreditated) & 2,65 & Ready Enough \\
\hline Accreditated national journal & 2,81 & Ready Enough \\
\hline Reputed international journal & 2,52 & Ready Enough \\
\hline Journal of particular profession based on the science field & 2,65 & Ready Enough \\
\hline Proceeding of National Seminar & 3,43 & Ready \\
\hline Proceeding of International Seminar & 2,72 & Ready Enough \\
\hline
\end{tabular}

Based on the analysis results and interpretation results, we know that UM institution in term of macro shows that its readiness is classified as good in enhancing the quality of the students'scientific works. However, the faculty is in the process of implementing the Circular Letter from Kemendikbud Number 152/E/T/2012 about the Scientific Work Publication, and the Study Program is in the process of implementing the Circular Letter, and it is classified as ready enough.

From the aspect of the type of the scientific work of the students enhanced, it shows that bachelor thesis and paper are categorized as ready, while the magister thesis, synopsis of bachelor thesis, synopsis of magister thesis are catergorized as ready enough and the synopsis of dissertation is categorized as less ready.

From the aspect of the media type, journal of study program and national smeinar proceeding are categorized as good while the others show ready enough such as online journal/online media, journal of faculty (not accreditated), journal of college (not accreditated), journal of college (not accreditated), acreditated journal. International reputed journal.
Journal of certain profession based on the science field and the International Seminar Proceeding.

\subsection{Supporting Factors of Institution in Enhancing the Quality of the Students' Scientific Work}

Based on the research data analysis, we can see that the description of the supporting factors of institution in enhancing the quality of students' scientific paper is categorized as good except reward aspect. The details of each supporting factor are presented in Table 2.

Based on the Table 2, there were the support from the chairmen of university (rectorate), the chairmen of faculty, the chairmen of

department/study program, manager of scientific paper, scientific paper writing \& publication advisory and training for student, the students' readiness in writing and publishing scientific paper, the students' motivation in using the lecturer's scientific paper as the reference in the lecture, the students' motivation in using scientific paper as the reference and those factors were classified as good.

Table 2. Supporting Factor of Institution in Enhancing the Quality of Students' Scientific Paper Publication

\begin{tabular}{|l|c|c|}
\hline \multicolumn{1}{|c|}{ Aspect } & Mean & Classification \\
\hline Supporting Factors & & \\
\hline Support of the chairmen of university (rectorate) & 3,48 & Good \\
\hline Support of the chairmen of faculty & 3,56 & Good \\
\hline Support of the chairmen of Department/Study Program & 3,56 & Good \\
\hline Support of the scientific paper manager & 3,41 & Good \\
\hline Advisory and training of scientific paper writing for students & 3,13 & Good \\
\hline Students' attitude in writing and publishing scientific paper & 3,33 & Good \\
\hline Students' motivation in writing and publishing scientific paper & 3,35 & Good \\
\hline
\end{tabular}




\begin{tabular}{|l|c|c|} 
Students' readiness in writing and publishing scientific paper & 3,15 & Good \\
\hline $\begin{array}{l}\text { Students' motivation in using the lecturer's scientific paper as the } \\
\text { reference in the lecture }\end{array}$ & 3,04 & Good \\
\hline Students' motivation in using scientific paper as the reference & 3,33 & Good \\
\hline Financial-reward (royalty) of Scientific Paper Result & 1,41 & Less good \\
\hline Non-financial reward of students' scientific paper & 1,76 & Less good \\
\hline \multicolumn{1}{|c|}{ Classification } & $\mathbf{3 , 0 4}$ & Good \\
\hline
\end{tabular}

However, the royalty and non-financial reward of students' scientific paper is categorized as less good.

\subsection{Inhibiting Factors in Enhancing the Quality of Students' Scientific Paper}

Based on the research data analysis, the inhibiting factors of the institution in improving the quality of students' scientific paper still existed in this research. The classification of the factors was categorized as less supporting to the students' scientific work publication enhancement. The details information of this result are presented in Table 3.

Table 3. Inhibiting Factors of Institution in Enhancing the Quality of Students' Scientific Paper Publication

\begin{tabular}{|l|c|c|}
\hline \multicolumn{1}{|c|}{ Aspect } & Mean & Classification \\
\hline Inhibiting Factors & & \\
\hline Support of the chairmen of university (rectorate) & 2,20 & Good enough \\
\hline Support of the chairmen of faculty & 2,20 & Good enough \\
\hline Support of the chairmen of Department/Study Program & 2,31 & Good enough \\
\hline Support of the scientific paper manager & 2,20 & Good enough \\
\hline $\begin{array}{l}\text { Advisory and training of scientific paper writing for } \\
\text { students }\end{array}$ & 2,31 & Good enough \\
\hline $\begin{array}{l}\text { Students' attitude in writing and publishing scientific } \\
\text { paper }\end{array}$ & 2,26 & Good enough \\
\hline $\begin{array}{l}\text { Students' motivation in writing and publishing scientific } \\
\text { paper }\end{array}$ & 2,24 & Good enough \\
\hline $\begin{array}{l}\text { Students' readiness in writing and publishing scientific } \\
\text { paper }\end{array}$ & 2,20 & Good enough \\
\hline $\begin{array}{l}\text { Students' motivation in using the lecturer's scientific } \\
\text { paper as the reference in the lecture }\end{array}$ & 1,17 & Less good \\
\hline $\begin{array}{l}\text { Students' motivation in using scientific paper as the } \\
\text { reference }\end{array}$ & 1,20 & Less good \\
\hline Financial-reward (royalty) of Scientific Paper Result & 1,46 & Less good \\
\hline Non-financial reward of students' scientific paper & 1,28 & Less good \\
\hline \multicolumn{1}{|c|}{ Classification } & Less good \\
\hline
\end{tabular}

Based on table 3, there are inhibiting factors of the students' quality enhancement derived from the chairmen of university (rectorate), the chairmen of faculty, the chairmen of department/study program, the scientific work publication manager, advisory and training of scientific paper writing for students, the students' attitude in writing and publishing scientific paper, and the readiness of the students in writing and publishing scientific paper as well as the scientific paper publication. Those factors are classified as ready enough. In addition, the students'motivation in using their lecturers'scientific works as the reference of their lectures and their scientific works are classified as good, financial and non financial rewards. 


\subsection{The Strategy of Institution in Enhancing the Quality of Students' Scientific Work Publication}

Based on the research data analysis, the strategy of the institution in enhancing the quality of the students' scientific work publication in this research is classified as good, but the recommendation is classified as less. The detail information of this case is presented in Table 4.

Based on the research analysis result in table 4, we know that the strategy of the institution in enhancing the students' scientific work quality is classified as good. The strategies are for example, the college issues a policy of scientific work publication becomes a requirement of graduation of the bachelor and Magister students, guides and trains the students in writing and publishing the scientific work in every semester, forms a special team to guarantee the quality of writing and publication of scientific work, provides the media of scientific work publication, facilitates or accompanies in writing and publishing the scientific work, helps to process the scientific work publication fastly, properly and professionally.

Table 4. The Strategy of Institution in Enhancing the Students' Scientific Work Publication

\begin{tabular}{|c|c|c|}
\hline Aspect & Mean & Classification \\
\hline \multicolumn{3}{|l|}{ Strategy in Enhancingthe Quality } \\
\hline $\begin{array}{l}\text { University issues a policy stating that scientific work publication } \\
\text { becomes the requirement of the student graduation in S1, S2, and } \\
\text { S3 programs }\end{array}$ & 3,50 & Good \\
\hline $\begin{array}{l}\text { University PT guides and trains the students in writing and } \\
\text { publishing the scientific work every semester }\end{array}$ & 3,43 & Good \\
\hline $\begin{array}{l}\text { University makes a special team to guarantee the quality of } \\
\text { scientific work writing and publication }\end{array}$ & 3,31 & Good \\
\hline University provides the media of scientific work publication & 3,50 & Good \\
\hline $\begin{array}{l}\text { University helps to make the process of scientific work writing } \\
\text { easy }\end{array}$ & 3,48 & Good \\
\hline $\begin{array}{l}\text { University helps to facilitate and accompany in publishing } \\
\text { scientific work }\end{array}$ & 3,46 & Good \\
\hline $\begin{array}{l}\text { University processes the scientific work publication fastly, } \\
\text { appropriately and professionally }\end{array}$ & 3,28 & Good \\
\hline Classification & 3,42 & Good \\
\hline \multicolumn{3}{|l|}{$\begin{array}{l}\text { Recommendation of university in Enhancing the Scientific } \\
\text { Work Quality }\end{array}$} \\
\hline $\begin{array}{l}\text { Publikasi karya ilmiah sebagai kewajiban untuk persyaratan } \\
\text { kelulusan mahasiswa S1, S2, dan S3. }\end{array}$ & 3,54 & Good \\
\hline $\begin{array}{l}\text { Publikasi karya ilmiah sebagai bukan kewajian (sunah) untuk } \\
\text { persyaratan kelulusan mahasiswa } \mathrm{S} 1, \mathrm{~S} 2 \text {, dan } \mathrm{S} 3\end{array}$ & 2,56 & Good enough \\
\hline $\begin{array}{l}\text { Publikasi karya ilmiah sebagai tidak menjadi persyaratan } \\
\text { kelulusan mahasiswa S1, S2, dan S3. }\end{array}$ & 2,26 & Good enough \\
\hline Classification & 2,78 & Good enough \\
\hline
\end{tabular}

There are some recommendations of the university in improving the quality of scientific work publication. One of them is scientific work writing is an obligation of students of S1, S2 and S3 programs to graduate and the respondents state that such recommendation is good. However, the recommendations stating that (1) scientific work publication is not an obligation of the student's graduation (just a suggestion) and (2) scientific work publication is not a requirement for the students to graduate from S1, S2 or S3 programs are considered as good enough by the respondents. Some other suggestions are needed for international scientific work publication. 


\section{DISCUSSION}

\subsection{The Readiness of Institution in Enhancing the Quality of Students' Scientific Work Publication}

The research results show that the readiness of institution in improving the quality of scientific work publication was classified as good. However, the aspect of implementing the Circular letter of General Directorate of Kemendikbud 152/E/T/2012 was categorized as ready enough. It means that the readiness of implementation process as the obligation of institution publication still have problems and thus the number of scientific paper publication is still rare. This phenomenon is in line with the fact that scientific paper from Indonesian university is still low. If Indonesia is compared to its countries like Malaysia, Indonesia is one of seven of Malaysia [2]. In other words, the effort of enhancing the quality and quantity of scientific paper publication is very urgent to do.

The ready publications are usually from Bachelor thesis or paper, while the ones that are from Magister thesis, synopsis of bachelor thesis and Magister thesis are classified as ready enough. The publications from Magister and doctoral thesis are not as ready as the ones which are from the Bachelor thesis.

From the aspect of media type used, journal of study program and national seminar proceeding show good readiness while the others show ready enough like online/online media journal, faculty journal (not accredited), university journal (not accredited), accredited national journal, international reputed journal, special profession journal based on the science field and international seminar proceeding.

\subsection{Supporting Factor of Institution in Enhancing the Quality of Students' Scientific Work}

Based on the research data analysis, the supporting factors of the institution in improving the quality of the students' scientific work in this research are categorized as good except the aspect of reward that is still low. This case shows that the support from the chairmen of the university, scientific publication manager and other stakeholders in scientific work writing has indicated positive so the students' attitude, motivation, and readiness are positive as well. All those things are definitely needed and support in enhancing the scientific work publication in the university.
However, the financial reward (royalty) and the non-financial reward to the students' product of scientific paper are classified as enough. It means that the barrier happens if the support is not optimal. Giving the reward to the students who successfully published their scientific papers is very significant, and the university will also get the long term benefit.

\subsection{Inhibiting Factors of Institution in Enhancing the Quality of the Students' Scientific Work Publication}

Based on the research data analysis, the inhibiting factors of the institution in enhancing the quality of the students' scientific work publication still existed. The inhibiting factors are categorized as less supporting the students' scientific work publication enhancement.

The chairmen, scientific publication manager as well as other stakeholders supporting the students' scientific paper publication enhancement are classified as supporting enough. This case was influenced by the unfortunate condition or barrier that was the weak motivation of students in using any lecturer's scientific paper product for their lectures. The students' motivation in using the scientific paper is only classified as good enough. Besides, the financial reward (royalty) and nonfinancial reward to the product of scientific paper in the university are categorized as less supporting. Such condition could possibly decrease the motivation to write a scientific paper.

\subsection{The Strategy of Institution in Enhancing the Quality of the Students' Scientific Work Publication}

The strategy of the institution in enhancing the quality of the students' scientific work publication in this research is categorized as good but the recommendation of scientific work publication quality enhancement is categorized as less good. The preeminent programs of scientific work development published in the international journals are urgently required to upgrade the competition ability of university in the future[10] or in the form of other programs, especially dealing with the international publications as the product of research or conceptual. The achievement of such international publication development programs is necessary to support the success of university in repairing its rank in the global world. 


\section{CONCLUSION AND RECOMMENDATION}

\subsection{Conclusion}

The readiness of university in enhancing the quality of the students' scientific paper publication is categorized as good. However, the process of implementing the Circular Letter of Dirjen Dikti Number 152/E/T/2012 about scientific work publication is classified as enough. From the aspect of the type of scientific work, bachelor thesis and paper are categorized as ready, while Magister thesis, synopsis of bachelor thesis, synopsis of Magister thesis is classified as ready enough and the synopsis of the dissertation is classified as less. From the aspect of the type of media used, the ready ones are the journals of study programs and proceeding of national seminar. Meanwhile, the other media are categorized as ready enough such as online journal/online media, journal of faculty (not accredited), journal of university (not accredited), international reputed journal, journal of particular profession based on the field and proceeding of international seminar.

The supporting factors in enhancing the quality of students'scientific work are the chairmen, scientific publication manager, students and students' motivation and all of them are categorized as good. However, the financial reward (royalty) and non-financial reward to the students'scientific works are classified as enough.

The inhibiting factors in improving the quality of students'scientific work are the chairmen of the institution who are less optimal, the scientific work publication manager, the guidance and training which are not optimal, the students attitude in writing and publishing scientific work, the students'motivation in writing and publishing the scientific work and the readiness of the students as well as the lack of reward.

Strategy done by the university is by obligating the students of S1, S2, and S4 programs to produce scientific work as the requirement for graduation and it is a good policy that should be conditioned including international scientific work publication.

\subsection{Recommendation}

Based on the conclusion of this research, there are some recommendations as follow: (1) the students of S2 and S3 programs should be encouraged more to publish their scientific works in the required journal more consistently, (2) the institution and the chairmen should provide consistent and progressive rewards to the authors so they can always improve the quality of their scientific works subsequently, (3) the commitment of the chairmen should be enhanced in preparing the students to improve the quality of their scientific works to be published in the required journal, and (4) the institution should orient the students'scientific work publication to the international journal.

\section{REFERENCES}

[1] Dirjen Dikti . 2012. Surat Edaran Dirjen Dikti Nomor 152/E/T/2012 tentang Publikasi Karya Ilmiah. Jakarta: Dikti.

[2] Zain, N. F. M. 2013. Masih Butuh Waktu. (Online), (http://edukasi.kompasiana. com/ 2012/03/14/masih-butuh-waktu), Diakses pada tanggal 15 Pebruari 2013.

[3] Bachtiar. 2012. Reputasi Publikasi Ilmiah Indonesia dan ASEAN. Kompasiana. Diakses 27 Pebruari 2013.

[4] Wikipedia. 2013. Publikasi ilmiah. (Online), (http: www.wikipedia.org). Diakses pada tanggal 27 Pebruari 2013.

[5] Nong, N.E. 2012. Pro Kontra Kewajiban Publikasi Karya Ilmiah. (Online). Diakses 20 Pebruari 2013.

[6] Arif, A. Mengkaji Kebijakan Publikasi Publikasi Karya ilmiah, Suara Merdeka, 11 Pebruari 2012.

[7] Bimfi, A. 2013. Ini Alasan Mahasiswa Wajib Publikasi Makalah. (online). (http://bimgi.bimkes.org). Diakses pada tanggal 28 Pebruari 2013.

[8] Arikunto, S. 2006. Arikunto, S. 2006. Prosedur Penelitian Suatu Pendekatan Praktek (Edisi Revisi VI). Yogyakarta: Rineka Cipta.

[9] Dharma, S. 2008. Pendekatan, Jenis, Dan Metode Penelitian Pendidikan. Depdikbud: Jakarta

[10] Lukman, R., Krajnc, D.\& Glavic, P.2009. University ranking using research, educational and environmental indicators. Journal of Cleaner Production, p: 1-10. 